\title{
Antibody-independent protection against Pseudomonas aeruginosa infection in mice after treatment with a homologous strain vaccine
}

\author{
T. FUJIMURA§, T. SUZUKI*, M. MITSUYAMAT, H. SAITO and K. NOMOTO‡
}

Department of Veterinary Microbiology, School of Veterinary Medicine, Kitasato University, Towada-shi, Aomori 034, Japan, "Kitasato Institute Hospital, Tokyo, † Department of Bacteriology, Niigata University School of Medicine, Niigata and $\ddagger$ Department of Immunology, Medical Institute of Bioregulation, Kyusyu University, Fukuoka, Japan

\begin{abstract}
Summary. Formalin-killed cells of Pseudomonas aeruginosa strain M-24 elicited an antibody-independent protective effect against $P$. aeruginosa infection in mice. The effect was observed as early as $6 \mathrm{~h}$ after administration and $100 \%$ protection was obtained by $48 \mathrm{~h}$. The protective effect could not be attributed to the production of specific antibody. In M-24-treated mice, the bacteria in the peritoneal cavity, blood and liver were eliminated $12 \mathrm{~h}$ after $P$. aeruginosa infection. This suggested that the protective effect was due to enhanced bacterial elimination. The percentage of macrophages in the peritoneal cavity was increased after M-24 administration. Furthermore, the enhanced bacterial elimination was abrogated by treatment of mice with ${ }^{60}$ Coirradiation or carrageenan. These findings suggest the involvement of macrophages in the enhanced bacterial elimination observed. The chemiluminescence of peritoneal exudate cells from M-24-treated mice was markedly increased when compared with that of cells from untreated mice. The ability to kill $P$. aeruginosa in vitro was also greater in macrophages from mice treated with killed M-24 than in cells from proteose-peptone-treated mice. The M-24-treated mice showed enhanced nonspecific protection against infection with lethal doses of $P$. aeruginosa, Escherichia coli or Listeria monocytogenes. However, susceptibility to LPS in mice was not increased by M-24 treatment. These results suggest that macrophage activation without increasing LPS susceptibility was responsible for the antibody-independent protection induced by killed M-24.
\end{abstract}

\section{Introduction}

Pseudomonas aeruginosa is one of the most important causes of nosocomial infections that are frequently lethal in burned and other compromised hosts (Benett, 1974; Reinharz et al., 1979; Lieberman et al., 1980). In veterinary medicine, it is also an important pathogen that causes haemorrhagic pneumonia in minks (Shimizu et al., 1974). It has been reported that vaccination with killed whole cells of $P$. aeruginosa protects animals against infection (Halen et al., 1966). The effect of vaccination is believed to be mediated by specific antibodies. In 1971, we encountered pyocyanosis in minks at a mink breeding ground in Aomori Prefecture, Japan. We immediately isolated the

Received 26 Oct. 1987; revised version accepted 20 June 1988. $\S$ Present address : Department of Bacteriology, Niigata University School of Medicine, Niigata 951, Japan. causative bacterium, $P$. aeruginosa strain $\mathbf{M}-24$, and administered formalin-killed whole cells as an autogenous vaccine to all the minks on the farm. The effect was outstanding; no more animals contracted the disease after inoculation with the killed M-24 vaccine even though an outbreak had already started (Saito et al., 1972). We did not determine whether the effect was antibody-mediated, or, as we suspected, the result of some antibody-independent mechanism judging from its rapid effect. In the present study, we have investigated the protective mechanisms which are induced shortly after administration of killed M-24 in mice.

\section{Materials and methods}

Mice

Specific pathogen-free BALB/c female mice (6-8 weeks old) were used in the experiments. The mice were 
obtained from Shizuoka Laboratory Animal Center, Shizuoka, Japan. Each experimental group consisted of 5-10 mice.

\section{Bacteria}

$P$. aeruginosa strain M-24, Listeria monocytogenes strain EGD, Escherichia coli strain O26:K60, and Klebsiella pneumoniae ATCC 27736 were used. P. aeruginosa, E. coli and $K$. pneumoniae were cultured on Tryptose Agar (Difco) at $37^{\circ} \mathrm{C}$ for $18 \mathrm{~h}$ for use in each experiment. $L$. monocytogenes was cultured in Tryptic Soy Broth (Difco) at $37^{\circ} \mathrm{C}$ for $12-18 \mathrm{~h}$. Afterwards, the cells were washed repeatedly, suspended in phosphate-buffered saline (PBS), and stored at $-70^{\circ} \mathrm{C}$.

\section{Preparation of killed cells of strain $M-24$ and determination of protective effect}

$P$. aeruginosa strain $\mathrm{M}-24$, isolated from a mink, was cultured on Heart Infusion Agar (Difco) at $37^{\circ} \mathrm{C}$ for $18 \mathrm{~h}$. After overnight treatment with formalin $0.4 \%$ in PBS, the concentration of killed bacteria was adjusted to $2.5 \times$ $10^{8}$ cells $/ \mathrm{ml}$ with PBS and used as a killed vaccine. Mice were given intraperitoneal injections of $0.2 \mathrm{ml}$ of the killed strain M-24 (5 $\times 10^{7}$ formalin-killed bacteria). To assess the protective effect of the vaccine, groups of mice were challenged intraperitoneally with a lethal dose of viable $P$. aeruginosa $6,12,24,48$ or $72 \mathrm{~h}$ after treatment with killed vaccine. Survival of mice was recorded for 7 days.

\section{Determination of antibody levels}

After inoculation of the killed M-24 cells, blood samples were collected over a period for the assay of antibodies against whole cells, original endotoxin protein (OEP), and elastase and protease from $P$. aeruginosa. Groups of mice were given the killed vaccine 7,3 or 2 days before the blood sampling. On the same day, serum from individual mice was collected, heat inactivated, and two-fold dilutions were made with PBS. The antibody against whole cells was assayed by agglutination of the formalinised cells. Diluted serum samples $(25 \mu \mathrm{l})$ were each mixed with an equal volume of suspension of formalinised cells $\left(\mathrm{OD}_{660}=0.2\right)$ in the well of a 96-well microtitration plate (Falcon 3911, U-bottomed). After incubation at $37^{\circ} \mathrm{C}$ for $2 \mathrm{~h}$, then at $4^{\circ} \mathrm{C}$ overnight, the highest dilution showing macroscopic agglutination was taken as the antibody titre. The antibodies against OEP, elastase and protease were assayed by the microtitration method of Homma (Tomiyama et al., 1973) with sensitised red-blood cells.

\section{Determination of the bacterial count}

Mice were inoculated with $1 \times 10^{7}$ viable bacteria in PBS, or $1 \times 10^{8}$ bacteria intravenously. At various times after inoculation, blood was collected by cardiac punc- ture, then the liver was removed. Individual organs were homogenised in $10 \mathrm{ml}$ of PBS with Teflon homogenisers. The homogenised suspensions and blood were serially diluted in 10-fold steps with PBS, and $0.1 \mathrm{ml}$ of each dilution was spread on to tryptose agar. Each dilution was plated in triplicate. Colonies were counted after incubation for $20 \mathrm{~h}$ at $37^{\circ} \mathrm{C}$.

\section{${ }^{60}$ Coirradiation}

Mice were exposed to $500 \mathrm{R}$ of whole body ${ }^{60}$ Coirradiation and infected 2 days later. The radiation was delivered by a Hitachi TRC-300 machine.

\section{Carrageenan}

Carrageenan type II (Sigma Chemical Co., St Louis, MO, USA) was dissolved in distilled water to a concentration of $5 \mathrm{mg} / \mathrm{ml}$ and injected intraperitoneally at a dose of $200 \mathrm{mg} / \mathrm{kg} 24 \mathrm{~h}$ before infection.

\section{Differential cell counts of peritoneal cells}

Cold Hanks's Balanced Salts Solution (HBSS) was injected intraperitoneally into mice and peritoneal cells were collected. Differential cell counts were performed with ANAE-stained smears (Horwitz et al., 1977) by light microscopy.

\section{Luminol-dependent chemiluminescence assay}

Peritoneal exudate cells (PEC) were harvested from seven mice $48 \mathrm{~h}$ after injection of killed M-24 and also from seven untreated mice. Pooled PEC were washed twice and resuspended to give $3 \times 10^{7}$ cells $/ \mathrm{ml}$ in Buffer II-HEPES-buffered salt solution containing $145 \mathrm{mM}$ $\mathrm{NaCl}, 5 \mathrm{~mm} \mathrm{KCl}, 5.5 \mathrm{~mm}$ glucose, $10 \mathrm{~mm}$ HEPES, pH7.4 (Labo Science Co., Tokyo, Japan). In a polystyrene tube, $50 \mu \mathrm{l}$ of the PEC suspension $\left(1.5 \times 10^{6}\right.$ cells $)$ were mixed with $0.05 \mathrm{ml}$ of Buffer I (Buffer II supplemented with $1 \mathrm{mM} \mathrm{CaCl}_{2}$ ). Then $0.2 \mathrm{ml}$ of a suspension of $P$. aeruginosa adjusted to $1.5 \times 10^{8} \mathrm{cfu} / \mathrm{ml}$ in Buffer II was added. As luminophor, $0.1 \mathrm{ml}$ of luminol solution (Labo Science Co.) was added. The luminescence was measured in a Lumiphotometer TD-4000 (Labo Science Co.).

\section{Phagocytosis and intracellular killing in vitro}

This was performed by a modification of the method of Miyata et al. (1984). PEC were harvested from the peritoneal cavity of mice 3 days or 2 days after injection of $2 \mathrm{ml}$ of proteose-peptone (Difco) $10 \% \mathrm{w} / \mathrm{v}$ or killed M24 , respectively. In each case, about $70 \%$ of the cells were macrophages. Proteose-peptone-induced PEC $\left(5 \times 10^{6}\right)$ or killed M-24-induced PEC $\left(5 \times 10^{6}\right)$ were mixed with $2.5 \times 10^{6}$ viable $P$. aeruginosa cells in RPMI 1640 medium supplemented with gelatin $0.1 \%$ and fresh normal mouse serum $5 \%$. The mixtures were incubated with stirring at $37^{\circ} \mathrm{C}$. Samples were collected after $0,30,60,90,120$ and 
$150 \mathrm{~min}$. The PEC were disrupted with cold distilled water, and the viable bacteria inside and outside the cells were counted by culture on tryptose agar.

\section{Cytostatic activity of peritoneal macrophages}

PEC were washed three times with HBSS and suspended to give $4 \times 10^{6}$ cells $/ \mathrm{ml}$ in RPMI 1640 medium supplemented with fetal calf serum (FCS) $10 \%$. After plating $2 \times 10^{5}$ or $4 \times 10^{5} \mathrm{PEC}$ in microculture plates, they were incubated for $2 \mathrm{~h}$ in a $\mathrm{CO}_{2}$ incubator at $37^{\circ} \mathrm{C}$. Nonadherent cells were removed by washing twice with warm HBSS plus FCS $10 \%$. P-815 mastocytoma cells were added, $2 \times 10^{4}$ cells $/$ well, and cultured for $15 \mathrm{~h}$. The mixed cultures were pulsed with ${ }^{125} \mathrm{I}-\mathrm{UdR}$ and incubated for a further $9 \mathrm{~h}$. The cells were harvested on filter paper with a Labo Mash Semi Automatic Harvester (Labo Science Co.). The incorporation of ${ }^{125} \mathrm{I}-\mathrm{UdR}$ into P-815 cells was counted in a $\gamma$-counter. The rate of cytostasis was determined according to the following formula:

Percentage cytostasis

$$
=\left(1-\frac{\mathrm{cpm} \text { target cells with immune cells }}{\mathrm{cpm} \text { target cells with control cells }}\right) \times 100
$$

\section{Non-specificity of the effect of $M-24$ treatment}

The killed M-24 vaccine was injected into mice, and $48 \mathrm{~h}$ later the mice were challenged with lethal doses of $P$. aeruginosa, E. coli, $K$. pneumoniae or $L$. monocytogenes. Seven days after the challenge, the cumulative survival rate was calculated for each group of mice.

\section{Susceptibility of M-24-treated mice to a lethal dose of lipopolysaccharide (LPS)}

LPS from E. coli, strain O111:B4 (Difco) was dissolved in PBS at concentrations of 300,400 or $500 \mu \mathrm{g} / \mathrm{ml} ; 48 \mathrm{~h}$ after injection of the killed M-24, each concentration of LPS was injected intraperitoneally into groups of mice, and their survival was observed for 7 days.

\section{Statistical analysis}

Statistical significance of the experimental data was examined by Student's $t$ test. A p value $<0.05$ was taken as the level of significant difference.

\section{Results}

\section{Survival rates after challenge with $P$. aeruginosa}

The protective effect of killed M-24 against primary infection with $P$. aeruginosa was assessed. All of the untreated mice died by day 2 after challenge with $1 \times 10^{7} \mathrm{cfu}$ of viable bacteria. A significant level of protection was observed in mice treated with killed M-24. Even in mice given killed
M-24 $6 \mathrm{~h}$ before the challenge, $67 \%$ survived the infection. When mice were challenged 48 or $72 \mathrm{~h}$ after M-24 treatment, $100 \%$ survival was obtained (fig. 1).

\section{Determination of antibody levels}

$P$. aeruginosa-specific antibody was determined after inoculation of killed M-24. None of the sera obtained within $72 \mathrm{~h}$ after inoculation contained antibodies against OEP, elastase, protease, or whole cells of $P$. aeruginosa strain M-24 (table I). Wholecell agglutinating antibody was detected only in the sera obtained from mice 7 days after inoculation. These results suggested that the protective effect of killed M-24, which had been observed as early as $6 \mathrm{~h}$ after treatment, did not depend upon specific antibody.

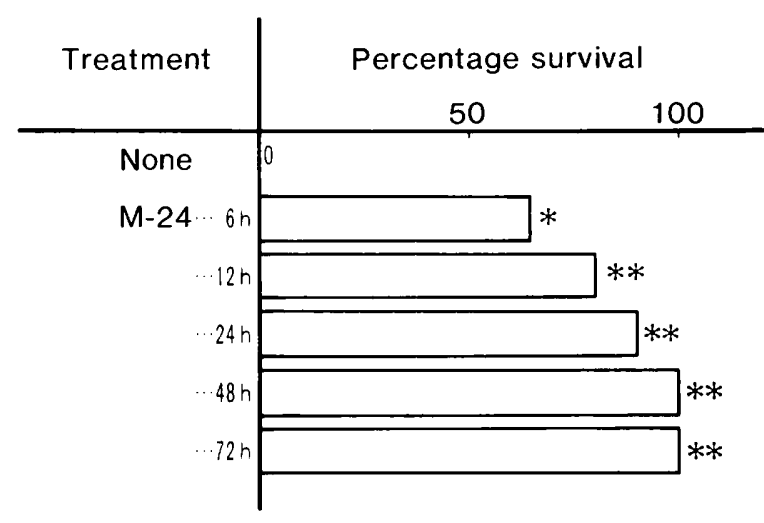

Fig. 1. Survival of mice after i.p. challenge with $1.0 \times 10^{7} \mathrm{cfu}$ of $P$. aeruginosa. Mice were treated i.p. with killed M-24 $6 \mathrm{~h}, 12 \mathrm{~h}$, $24 \mathrm{~h}, 48 \mathrm{~h}$ and $72 \mathrm{~h}$ before challenge. The survival rate was calculated for each group of 10 mice after observation for 7 days; ${ }^{*} \mathrm{p}<0.01{ }^{* *} \mathrm{p}<0.001$.

Table I. Titres of antibody to whole cells, OEP, elastase and protease after vaccination of mice with killed cells of P. aeruginosa strain M-24

Antibody titre to

\begin{tabular}{lcccc}
\cline { 2 - 5 } Mouse serum & Whole cell & OEP & Elastase & Protease \\
\hline $\begin{array}{c}\text { Pretreatment } \\
48 \text { h after }\end{array}$ & $<4$ & $<4$ & $<4$ & $<4$ \\
$\begin{array}{c}\text { treatment } \\
72 \text { h after } \\
\text { treatment }\end{array}$ & $<4$ & $<4$ & $<4$ & $<4$ \\
$\begin{array}{c}7 \text { days after } \\
\text { treatment }\end{array}$ & 32 & $<4$ & $<4$ & $<4$ \\
\hline
\end{tabular}


Effect of $M-24$ treatment on the elimination of $P$. aeruginosa

To determine whether the protective effect observed in a short period after killed M-24 treatment was attributable to enhanced bacterial elimination, bacterial numbers in various organs were estimated $12 \mathrm{~h}$ after the challenge. In untreated mice, injected bacteria seemed to spread easily from the peritoneal cavity throughout the body. In mice treated with killed M-24, the counts of viable bacteria in all organs examined were significantly lower $(p<0.001)$ than in organs from the untreated group. No viable bacteria were detected in the blood from the M-24-treated group (fig. 2).

\section{Changes in population of peritoneal cells}

Since it was evident that some mechanism other than specific antibody was playing a role in killed M-24-induced early protection, the population of peritoneal cells was determined. After an intraperitoneal injection of killed M-24 into mice, PEC were collected over a period and the cell population was analysed. A significant increase $(p<0.005)$ in macrophage numbers was observed as early as $24 \mathrm{~h}$ after injection of killed M-24. In contrast, lymphocytes showed a transient decrease in number (fig. 3 ). There was no marked change in the percentage of polymorphonuclear leucocytes (PMNLs).

\section{Effect of ionising radiation on killed M-24-induced protection}

Ionising radiation is reported to impair radiationsensitive phagocytic cells (Kaplan et al., 1952; Benacerraf et al., 1959; Volkman and Collins, 1971). To evaluate the contribution of phagocytic cells to killed M-24-induced protection, the effect

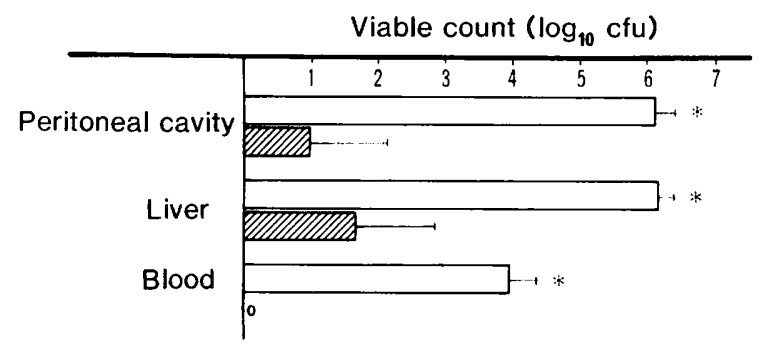

Fig. 2. Effect of treatment with killed M-24 on the elimination of $P$. aeruginosa. Mice were given $1 \times 10^{7} \mathrm{cfu}$ of $P$. aeruginosa, i.p., and the viable count in the peritoneal cavity, liver and blood was estimated $12 \mathrm{~h}$ later. $\square$-Mice treated i.p. with killed M-24 $48 \mathrm{~h}$ earlier; $\square$ untreated control mice. $\mathrm{I}=\mathrm{SD} ;{ }^{*} \mathrm{p}<0.001$.

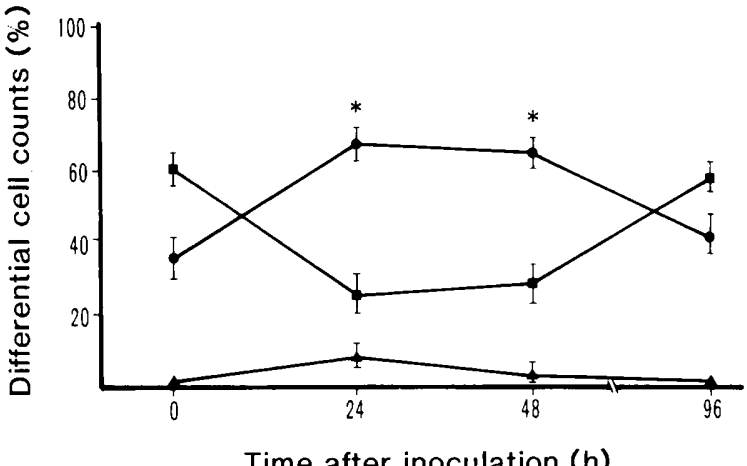

Time after inoculation ( $h$ )

Fig. 3. Changes in the population levels of PEC from mice after treatment with killed M-24: - - lymphocytes; - - macrophages; $-\mathbf{A}$ - PMNLs; $\mathrm{I}= \pm \mathrm{SD} ;{ }^{*} \mathrm{p}<0.005$.

of $500 \mathrm{R}$ of whole-body irradiation was determined on killed vaccine-induced protection. The group given killed M-24 showed a continuous elimination of the bacteria with time (fig. 4). In the untreated group, the bacteria were eliminated up to $8 \mathrm{~h}$ after infection, but thereafter bacterial growth was observed. The ${ }^{60}$ Coirradiated group showed a similar pattern of bacterial elimination but subsequent growth similar to that observed in the untreated group. Whole-body irradiation com-

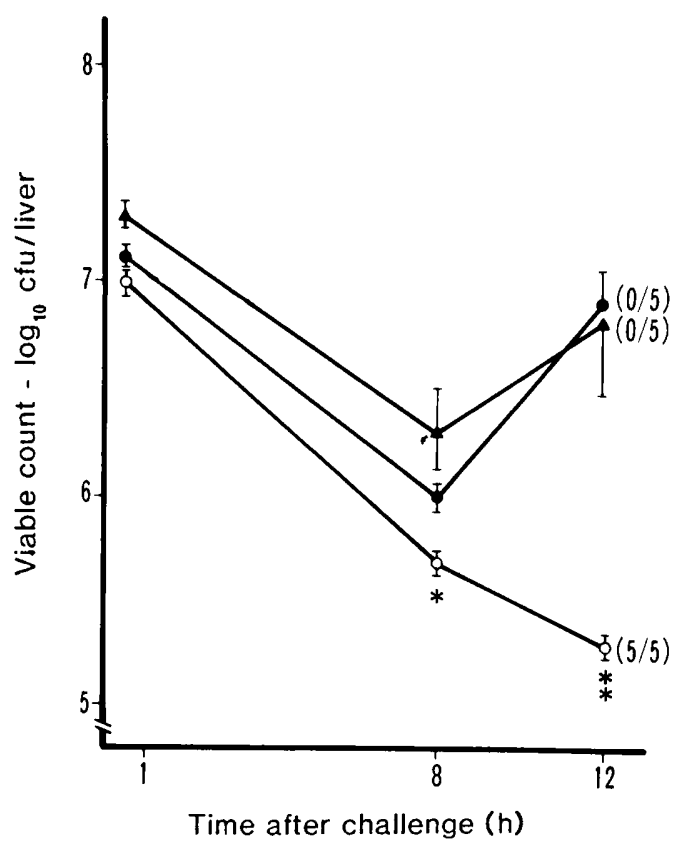

Fig. 4. Effect of 500 R-irradiation of mice on the bacterial count in livers: $\Delta$ untreated controls; ${ }^{60}$ Coirradiation, killed $\mathrm{M}-24$ treated mice; $O$ non-irradiated, killed M-24-treated mice. Each point indicates the mean $\pm S D$ for five mice. Survival rate is indicated in parenthesis. ${ }^{*} \mathrm{p}<0.05 ;{ }^{* *} \mathrm{p}<0.005$. 
pletely abrogated the bacterial elimination induced by killed $\mathrm{M}-24$, suggesting that a ${ }^{60}$ Coirradiationsensitive factor was involved in the expression of the protection in the killed M-24-treated group.

\section{Effect of carrageenan on the group treated with killed $M-24$}

This experiment was to study the effect of carrageenan, a macrophage blocking agent, on the protective effect of killed $\mathrm{M}-24$ against intravenous infection. In control animals, there was a significant difference $(\mathrm{p}<0.001)$ in the number of bacteria recovered between the group given killed M-24 and the untreated group $12 \mathrm{~h}$ after infection; this protection was completely abrogated by the treatment with carrageenan $24 \mathrm{~h}$ before the challenge (fig. 5). The number of bacteria in unvaccinated mice treated with carrageenan only was the same as that in untreated, unvaccinated mice. These results suggest that a carrageenan-sensitive factor, presumably macrophages, contributes to the enhanced bacterial elimination in the liver of the killed M-24-treated mice.

\section{Phagocytic activation of peritoneal macrophages as determined by luminol-dependent chemiluminescence}

Luminol-dependent chemiluminescence was measured to study the functional activation of PEC in mice given killed $M-24$. The peak response in the killed M-24-treated mice was about 45 times higher than that in the untreated mice $(p<0.001)$ (table II). The differential cell counts of PEC are also shown in table II. There was no significant difference in the proportion of PMNLs between two groups. The percentage of macrophages amongst cells from the killed M-24-treated group was about two-fold higher than in cells from the control group. Therefore, the vast difference in

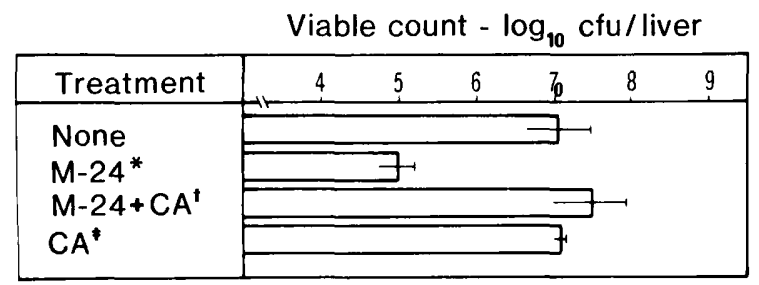

Fig. 5. Effect of carrageenan treatment on the bacterial count in the liver of killed M-24-treated mice. Mice were given $1 \times 10^{8}$ cfu of $P$. aeruginosa, i.v., and the viable count in the liver was determined $12 \mathrm{~h}$ later. $\mathrm{CA}=$ carrageenan; *mice treated i.p. with killed M-24 $48 \mathrm{~h}$ earlier; $†$ mice treated i.p. with killed $\mathrm{M}$ $2448 \mathrm{~h}$ earlier and with CA $24 \mathrm{~h}$ before challenge; $\ddagger$ mice treated i.p. with CA 24 h earlier; $I=$ mean $\pm S D$. peak chemiluminescence response between the two groups could not be explained only by the difference between the absolute numbers of macrophages in a given number of test cells. This strongly suggested that the peritoneal macrophages in the killed $\mathrm{M}$ 24-treated mice were in an activated state.

\section{Determination of macrophage activity in vitro}

In this experiment, proteose-peptone-induced PEC were used as control cells so that the same percentage of macrophages were obtained as in PEC from mice given killed M-24. The ability of macrophages to kill $P$. aeruginosa in vitro was greater in the mice treated with killed M-24 than that in proteose-peptone-treated mice (fig. 6). When these PEC were examined for their cytostatic activity against P-815 mastocytoma cells, macrophages from killed M-24-treated mice showed an increased cytostasis by $50-60 \%$ compared to those from mice injected with proteose peptone (not shown). These results strongly suggested that the macrophage activity in killed M-24-treated mice was higher that that in control mice stimulated with peptone.

\section{Non-specificity of the protective effect of killed M-24}

As shown in table III, killed M-24-treated mice were protected against infection by a lethal dose of

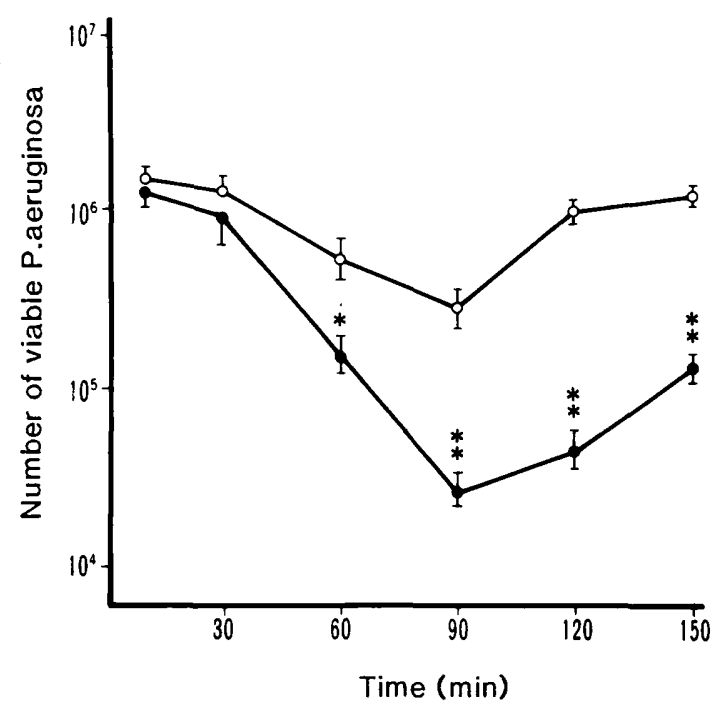

Fig. 6. Killing of $P$. aeruginosa by PEC from killed M-24 treated mice :-O-PEC from proteose-peptone-treated mice (mice were given $2 \mathrm{ml}$ of proteose peptone, i.p., 3 days before); - - PEC from M-24-treated mice (mice were given $0.2 \mathrm{ml}$ of killed M-24, i.p., 48 h earlier; $I=$ mean $\pm S D ;{ }^{*} p<0.005 ;{ }^{* *} p<0.001$. 
Table II. Chemiluminescence response of mouse peritoneal cells to $P$. aeruginosa

\begin{tabular}{lcccc}
\hline & \multicolumn{3}{c}{ Percentage of cells } & \\
\cline { 2 - 4 } $\begin{array}{l}\text { Animal } \\
\text { treatment }\end{array}$ & Monocytes & PMNLs & Lymphocytes & $\begin{array}{c}\text { Peak response (cps) } \\
(\text { mean } \pm \text { SD) }\end{array}$ \\
\hline None & 36.0 & 1.0 & $61 \cdot 5$ & $283.3 \pm 33 \cdot 3$ \\
Killed M-24 $\left(-48 h^{*}\right)$ & 64.5 & 2.5 & 28.5 & $11766.7 \pm 33 \cdot 3 \dagger$ \\
\hline
\end{tabular}

PMNLs = polymorphonuclear leucocytes.

* Mice were given $0.2 \mathrm{ml}$ of killed M-24, i.p., $48 \mathrm{~h}$ earlier. $\dagger \mathrm{p}<0.001$.

Table III. Non-specificity of the protective effect induced by killed M-24

\begin{tabular}{|c|c|c|c|c|c|}
\hline \multirow[b]{2}{*}{ Bacteria } & \multirow{2}{*}{$\begin{array}{l}\text { Route of } \\
\text { challenge }\end{array}$} & \multirow{2}{*}{$\begin{array}{l}\text { Challenge } \\
\text { dose }\end{array}$} & \multicolumn{2}{|c|}{ Percentage survival in mice* } & \multirow[b]{2}{*}{$p$ value } \\
\hline & & & untreated & M-24 treated $\uparrow$ & \\
\hline \multirow{2}{*}{ P. aeruginosa } & i.v. & $1.0 \times 10^{8}$ & 0 & 90 & $<0.001$ \\
\hline & i.p. & $1.0 \times 10^{7}$ & 0 & 100 & $<0.001$ \\
\hline E. coli & i.p. & $1.0 \times 10^{9}$ & 0 & 75 & $<0.05$ \\
\hline K. pneumoniae & i.p. & $7.6 \times 10^{8}$ & 0 & 50 & $<0.05$ \\
\hline \multirow{2}{*}{ L. monocytogenes } & i.v. & $1.0 \times 10^{6}$ & 0 & 100 & $<0.01$ \\
\hline & i.p. & $1.0 \times 10^{7}$ & 0 & 100 & $<0.01$ \\
\hline
\end{tabular}

† Mice treated i.p. with M-24 48 h earlier.

* Survival was calculated after observation for 7 days; each group consisted of 5 to 10 mice.

$P$. aeruginosa, E. coli or $K$. pneumoniae. Furthermore, $100 \%$ protection was observed against $L$. monocytogenes infection, protection against which depends on activated macrophages. This result indicated that the effector in M-24-induced protection was non-specific.

Susceptibility of the killed M-24-treated mice to the lethal effect of LPS

Some macrophage activating agents, including BCG and C. parvum, enhance susceptibility to the

Table IV. Susceptibility of mice treated with killed M-24 to lethal doses of LPS

Survival of mice at 7 days after LPS

\begin{tabular}{lcll}
\cline { 2 - 4 } Animal treatment & $300 \mu \mathrm{g}$ & $400 \mu \mathrm{g}$ & $500 \mu \mathrm{g}$ \\
\hline Untreated control & $4 / 5$ & $0 / 5$ & $0 / 5$ \\
Killed M-24* & $4 / 5$ & $3 / 5 \dagger$ & $2 / 5 \dagger$
\end{tabular}

* Mice treated i.p. with killed M-24 48 h earlier. $+\mathrm{p}<0.05$. lethal effect of LPS in animals (Peavy et al., 1979; Yoshikai et al., 1982, 1983; Lal et al., 1983). Therefore, we investigated whether there was any change in the susceptibility to LPS in mice after treatment with killed M-24. As shown in table IV, the killed M-24-treated mice showed increased resistance to lethal doses of LPS. Even after injection of $500 \mu \mathrm{g}$ of LPS, a $100 \%$ lethal dose for control mice, two mice out of five survived.

\section{Discussion}

As we had previously observed, killed M-24 induced a high level of protection against infection with $P$. aeruginosa in mice. The protection against $P$. aeruginosa appeared as early as $6 \mathrm{~h}$ after administration of killed M-24. Complete protection was obtained $48 \mathrm{~h}$ after administration; however, there was no detectable serum antibody at that time. When serum was taken $48 \mathrm{~h}$ after M-24 treatment and transferred to non-immune mice before challenge with a lethal dose of $P$. aeruginosa, there was no difference in the mortality of the recipient mice from control mice given normal serum (data not shown). These results suggest the 
induction of some antibody-independent protective mechanism by administration of killed M-24. A similar finding was reported previously by Jones (1971). A single injection of vaccine prepared from a culture filtrate of $P$. aeruginosa afforded a protective effect against infection with homologous bacteria as early as 2 days after vaccination. It was reported that specific antibody was not detected in the serum of vaccinated mice even on day 3 after vaccination, suggesting the possible contribution of non-specific factors other than antibodies to the early protective effect.

Mice treated with killed M-24 eliminated bacteria from the peritoneal cavity, liver and blood very efficiently. This observation indicated that the protection induced by killed M-24 was based on enhanced elimination of the bacteria. This was abrogated by whole-body ${ }^{60} \mathrm{Co}$ irradiation, which impairs both PMNLs and macrophage activity (Tatsukawa et al., 1979), as well as by treatment with carrageenan which impairs cells of the macrophage series only (Catanzaro et al., 1971). These findings suggested that macrophages were responsible for the killed $\mathrm{M}$-24-induced protection against $P$. aeruginosa. After treatment with killed M-24, about $70 \%$ of the PEC were macrophages, indicating an increase in macrophage count. There was no marked change in the percentage of PMNLs. We then investigated whether the enhanced elimination was due merely to a numerical increase or, in addition, due to enhanced activity of the macrophages. Phagocytes including monocytes, macrophages and PMNLs, emit luminescence with a peak at $570 \mathrm{~nm}$ during phagocytosis. Using our chemiluminescence assay as an indicator of the degree of activation of these cells, we found that chemiluminescence from PEC from killed M-24treated mice was $c .50$-fold greater than that of PEC from the control mice. This difference could not be attributed to the numerical difference of macrophages or PMNLs in the test cells.

Further evidence for macrophage involvement in M-24-induced protection was obtained by demonstrating enhanced ability of macrophage-rich PEC to kill $P$. aeruginosa in vitro. So-called activated macrophages possess antitumour activity (Keller, 1981; Meltzer, 1981). Macrophages from M-24treated mice were shown to possess enhanced cytostatic activity against P-815 mastocytoma cells. These results strongly indicated that macrophages are activated in mice $48 \mathrm{~h}$ after treatment with killed M-24. It has been suggested that antibody plays a crucial role in vaccine-induced protection against the development of sepsis and other lethal effects of infection with massive doses of $P$. aeruginosa (Fukutome et al., 1980). In this study, we have demonstrated a novel finding that an antibody-independent protection can be induced by killed $\mathrm{M}-24$ and that macrophage activation plays a major role in its expression.

An important approach to controlling infection with $P$. aeruginosa is immunisation with a vaccine capable of inducing specific antibodies. Another approach is the induction of non-specific resistance against $P$. aeruginosa. Both $C$. parvum and BCG activate macrophages when administered in vivo. However, it has been reported that mice treatment with C. parvum or BCG increases mortality in mice after infection with $E$. coli or $P$. aeruginosa (Peavy et al., 1979; Yoshikai et al., 1982, 1983; Lal et al., 1983). This phenomenon seems to be due to enhanced susceptibility to the lethal effect of LPS from gram-negative bacteria, which is induced in association with macrophage activation (Lal et al., 1983). In this respect, the non-specific resistance induced by killed M-24 is of considerable interest since macrophage activation could be obtained without accompanying increased susceptibility to LPS.

Bacterial endotoxin is one of several substances that activate macrophages (Allison, 1978). The effects of LPS-activated macrophages include tumour cell cytolysis and production of superoxide anion (William and Henson, 1978; Pabst and Johnston, 1980; Schade, 1986). Therefore, it is possible that LPS contained in the whole-cell preparation of killed M-24 was responsible for the macrophage activation observed in this study. It is also possible that LPS in killed M-24 might induce endotoxin tolerance. A dose of endotoxin as low as $10 \mu \mathrm{g}$ induced endotoxin tolerance with a peak at 24-48 $\mathrm{h}$, and this has been linked to antibodyindependent resistance to infection (Morrison and Ryan, 1979). We also induced endotoxin tolerance in mice by administering LPS from $E$. coli, and challanged the mice with a lethal dose of $P$. aeruginosa $48 \mathrm{~h}$ later. However, we did not observe any enhancement of the elimination of bacteria from liver, blood and peritoneal cavity as observed in M-24-treated mice (data not shown). Taken with our earlier findings, we conclude that the protective effect of killed M-24 was not simply due to endotoxin tolerance, but that macrophage activation, without an accompanying increase in LPS susceptibility, is playing an important role.

Whole cells of Lactobacillus casei have been reported to augment the host defence against infection by $P$. aeruginosa without increasing the susceptibility to LPS (Miake et al., 1985). Lipoteichoic acid from $L$. casei seems to be partly 
responsible for this protective effect (Setoyama et al., 1985). P. aeruginosa does not possess teichoic acid as a surface component so there must be some other component responsible for the macrophage activation and enhanced resistance to various species of bacteria as observed in this study. The

\section{REFERENCES}

Allison A C 1978 Macrophage activation and nonspecific immunity. International Review of Experimental Pathology 18: $303-346$

Benacerraf B, Kiry-Rosenberg E, Sebestyen M M, Zweifach B W 1959 The effect of high doses of X-irradiation on the phagocytic, proliferative, and metabolic properties of the reticulo-endothelial system. Journal of Experimental Medicine 110: 49-64.

Benett J V 1974 Nosocomial infections due to Pseudomonas. Journal of Infectious Diseases 130 Suppl: S4-S7.

Catanzaro P J, Schwartz H J, Graham R C 1971 Spectrum and possible mechanism of carrageenan cytotoxicity. American Journal of Pathology 64: 387-404.

Fukutome T, Mitsuyama M, Takeya K, Nomoto K 1980 Importance of antiserum and phagocytic cells in the protection of mice against infection by Klebsiella pneumoniae. Journal of General Microbiology 119 : 225-229.

Halen PH, Pohl P, Thomas J 1966 Septicemies à Pseudomonas chez les visons et chinchillas. Annales de Médecine Véterinaire 6 : 397-406.

Horwitz D A, Allison A C, Ward P, Kight N 1977 Identification of human mononuclear leucocyte populations by esterase staining. Clinical and Experimental Immunology 30: 289298.

Jones R J 1971 Early protection by vaccines in burns. British Journal of Experimental Pathology 52: 100-109.

Kaplan H S, Speck R S, Jawetz E 1952 Impairment of antimicrobial defences following total body irradiation of mice. Journal of Laboratory and Clinical Medicine 40: 682691.

Keller R 1981 The cytostatic and cytocidal effects of macrophages. In: Pick E (ed) Lymphokines, vol. 3. Academic Press, New York, pp 283-292.

Lal S, Mitsuyama M, Ogata N, Miyata M, Miake S, Nomoto K 1983 BCG-induced susceptibility of mice to challenge with Pseudomonas aeruginosa. Journal of General Microbiology 129: 93-98.

Lieberman M M, Wright G L, Wolcott K M, Mckissock-Desto D C 1980 Polyvalent antisera to Pseudomonas ribosomal vaccines: protection of mice against clinically isolated strains. Infection and Immunity 29 : 489-493.

Meltzer M S 1981 Tumor cytotoxicity by lymphokine-activated macrophages; development of macrophage tumoricidal activity requires a sequence of reactions. In: Pick E (ed) Lymphokines, vol. 3. Academic Press, New York, pp 319344.

Miake S, Nomoto K, Yokokura T, Yoshikai Y, Mutai M, Nomoto K 1985 Protective effect of Lactobacillus casei on Pseudomonas aeruginosa infection in mice. Infection and Immunity 48: 480-485.

Miyata M, Mitsuyama M, Ogata N, Nomoto K 1984 Protective mechanisms against infection by Listeria monocytogenes: responsible component of the whole-cell vaccine of $P$. aeruginosa $\mathrm{M}-24$ is being investigated further. So far, OEP and other fractions have failed to reproduce the effect shown by killed M-24. It is possible that several components are acting in combination.

accumulation and activation of macrophages. Journal of Clinical and Laboratory Immunology 13: 111-115.

Morrison D C, Ryan J L 1979 Bacterial endotoxins and host immune responses: VII Biomedical applications of endotoxin-activated immune systems. Advances in Immunology 28: 414-429.

Pabst M J, Johnston R B 1980 Increased production of superoxide anion by macrophages exposed in vitro to muramyl dipeptide or lipopolysaccharide. Journal of Experimental Medicine 151 : 101-114.

Peavy D L, Baughn R E, Musher D M 1979 Effects of BCG infection on the susceptibility of mouse macrophages to endotoxin. Infection and Immunity 24: 59-64.

Reinharz J A, Megna M J, Brown G T 1979 Nosocomial infection: time for accountability. In: Gilbert $D \mathrm{~N}$, Sandford J P (eds) Infectious diseases, current topics. vol. 1. Grune \& Stratton, New York, pp 219-240.

Saito H, Nakano K, Sakai T, Sato K, Shimoda K, Saito H 1972 Studies on the infectious disease of mink caused by Pseudomonas aeruginosa. The Japanese Journal of Veterinary Science 34: 185-186. (In Japanese).

Schade U F 1986 Involvement of lipoxygenases in the activation of mouse macrophages by endotoxin. Biochemical and Biophysical Research Communications 138: 842-849.

Setoyama T, Nomoto K, Yokokura T, Mutai M 1985 Protective effect of lipoteichoic acid from Lactobacillus casei and Lactobacillus fermentum against Pseudomonas aeruginosa in mice. Journal of General Microbiology 131 : 2501-2503.

Shimizu T, Homma J Y, Aoyama T, Onodera T, Noda H 1974 Virulence of Pseudomonas aeruginosa and spontaneous spread of Pseudomonas pneumonia in a mink ranch. Infection and Immunity 10: 16-20.

Tatsukawa K, Mitsuyama M, Takeya K, Nomoto K 1979 Differing contribution of polymorphonuclear cells and macrophages to protection of mice against Listeria monocytogenes and Pseudomonas aeruginosa. Journal of General Microbiology 115: 161-166.

Tomiyama T, Homma J Y, Abe C, Yoichi M 1973 Passive hemagglutination reaction using formalinized sheep erythrocytes treated with tannin and coated with protein moiety of the endotoxin (OEP) of Pseudomonas aeruginosa. Japanese Journal of Experimental Medicine 43: 185-189.

Volkman A, Collins F M 1971 The restorative effect of peritoneal macrophages on delayed hypersensitivity following ionizing radiation. Cellular Immunology 2: 552-566.

William F D, Henson P M 1978 Macrophage stimulation by bacterial lipopolysaccharides. I. Cytolytic effect on tumor target cells. Journal of Experimental Medicine 148: 544-556.

Yoshikai Y, Miake S, Mituyama M, Nomoto K 1982 Effects of Corynebacterium parvum on Escherichia coli infection in mice. Journal of General Microbiology 128 : 2857-2863.

Yoshikai Y, Miake S, Sano M, Nomoto K 1983 Increased susceptibility to Escherichia coli infection in mice pretreated with Corynebacterium parvum. Microbiology and Immunology 27: 273-282. 